\title{
An Analysis of the Attribute of Accounting Discipline from the Historical Process of Accounting Development
}

\author{
Wei Cong \\ Accounting Department, Jilin Business and Technology College, JLBTC, Chang Chun, China. \\ Email: xpxp333@163.com
}

Received July, 2013

\begin{abstract}
Undeniably, in today all aspects of the social life are inseparable from the accounting, but the position of accounting was unclear, and the academic circles debated ceaselessly. When we can not see the direction clearly, we can take a look back at history. From the history of the development process of accounting, we can look for the clues of the attribute of accounting. The history would give us a new perspective of the researching.
\end{abstract}

Keywords: Accounting; Accounting History; Economics; Management; Discipline Attribute

\section{Putting Forward the Problem}

Today, with the development of economy, the importance of accounting was prominent increasingly. There is the participation of accounting not only in the family who arranged the food, clothing, housing, transport entertainment, education and other daily necessities, but also in the government who made the monetary policy, fiscal policy, industrial development planning. Accounting is closely related with all of the above. That is, the economy is more developed, the accounting is more important, However, on the opposite of the status of accounting is increasing in the real economic life, in the academia, the localization of accounting is low, especially in China, at present, according to discipline and professional catalogue to confer doctor's and master's degree and postgraduate training promulgated at 1997 and the undergraduate professional catalogue of college and university issued at 1998, accounting vests in management, and is a branch of the enterprise management discipline. In addition, the academia always argued about that accounting is belonging to which discipline. There is not a conclusion, some one considers that accounting is belonging to the economics; some one considers it is belonging to management. In the practice of accounting research and education, there are also contradictory situation, on the one hand, accounting theory research use the economics theory largely, this seems to show that many scholars recognized that accounting is belonging to economics; On the other hand, the higher education often set up the accounting department in the business college, this tell us seemly that the attribute of the accounting is management. In the management practice of modern enterprise, the accountants and the accountancies also played the role of the generalist. On the one hand, accounting serviced for the enterprise management, especially the chief accountant was regarded as enterprise's senior manager, they participate in all major decision making processes of the enterprise; On the other hand, the accountants used the theory and method of economics to sort and process the data of enterprise operating, and then analyzed the economic meaning of the data.

Thus, it can be seen, not only in the researching by the academic, but also at the practical application, the disciplinary property of accounting is vague, this is the current situation. When we can not see the future, we can take a look back at history. From the development of the accounting history, we can find the rule, identify the direction.

\section{The Historical Analysis of the Development of Accounting}

From the humans began to engage in production activities in a planned way, the accounting was created. From the humans used the simple marks and intuitive drawings in the primitive society, though a long history, today the accounting has rich and colorful theories and practices. At each stage of development of the accounting, there were the most representative accounting theory or the method, thus we can not divide the history simply, and we must analyze the history deeply.

\subsection{Guan-Ting Accounting as a Representative of Ancient Accounting}

At first, accounting just was an ancillary work of produc- 
tion. Later, with the development of productive forces, the surplus products emerged, at the same time, the socialized production emerged, the division of labor emerged, from now on, accounting becomes a independent work gradually, it becomes a separate management function that is different with the production. In China, the word "Kuai-Ji" that means accounting first appeared in the western Zhou dynasty (the 11th century B.C. -- the 8th century B.C.). They mainly used the method that called "day end closing, month end closing and year end closing", i.e. they must submit accounting report in accordance with the different accounting period, and satisfy the ruler's need of recording and management the money and foodstuff in their region. In China, into the feudal society period, in order to consolidate the national domination further, strengthen the central economic centralization, the rulers of reformed the system of taxes, and improved the official organization of public finance and accounting, made a substantial progress than before, and gradually formed the perfect "Guan-Ting Accounting", i.e. government accounting. The same period in the other countries of the world, such as Europe, India and Japan also appeared similar situation. At this time, there were a interdependent relationship between the public finance and the accounting, the accounting work was base on the public finance, the public finance work relied on the accounting, they had a coordinate and inseparable relationship, so we can call it by a joint name, and to show there had an integration of organizational work relations in government financial revenue and expenditure management. At the same time, the folk accounting also had developed, but can not compare with Guan-Ting accounting on both the organizations and the methods, so it can not be the representative of the accounting development in this period.

\subsection{Financial Report Accounting as a Representative of Recent Accounting}

From the 14th to 16th century, the capitalist economic relations and budded and developed in the Europe, various company, such as commercial companies, banks and industrial companies emerged with a new attitude in the social economic life, consequently, the financial accounting whose main goal is to prepare accounting statement, emerged with a new gesture. The development of the company economic and the evolution of the company created a new milestone in the history of the accounting. By its push, the ancient accounting stepped into the recent development stage of the accounting, and the development of financial accounting gradually exceeded more than government accounting, and started to become the dominant position in the world accounting history. In this stage, the important development is mainly embodied in the two accounting statements, namely balance sheet and income statement appeared and applied. With the expansion of the company, the need for capital was increasingly strong. In order to solve this problem, the enterprise may choose to borrow a loan or seek new investors. In order to get loans, enterprise need to prove the debt paying ability and the ability to pay; In order to attract more investors, they need to prove the business performance and the ability to make a profit. Under this situation, the appearance and development of the balance sheet and the income statement also was the historically inevitable. In order to meet the requirements of the external information users, the accounting developed gradually from a simple internal accounting into a financial statement accounting whose main works was that submit accounting statements for outside, this model has become the development trend of the recent accounting, and has gotten the government approval and confirmation by the laws and regulations.

\subsection{Management Accounting as a Representative of Modern Accounting}

After the 1950s, the world economy development entered into a new period, the capitalist economic developed rapidly, the ever-changing technology had applied in production extensively, capital had concentrated further, thus the scale of enterprise expanded gradually, the group company, multinational companies emerged largely, and the production and business operation had been becoming increasingly complicated. The external market changed at every moment, and the competition was more intense. All of the above not only were the new requirements to the enterprise management modernization, but also promoted the enterprise management modernization objectively. The past productive management mode that the production was the center, had been adjusted into the business decision-making management mode whose centre was developing market, mobilizing the enthusiasm of each respect, and getting the maximum possible economic benefits. Then the virtuous circle could be realized under the condition of market economy. From now on the world steps into the new stage of the modern economic management. At this stage, in order to adapt to the requirements of the modern economic management, the scholars improved the theories and practices of the plan and control accounting, and gradually enriched the forecast decision accounting and responsibility accounting. The new system of modern management accounting that the forecast decision accounting was major supplemented by the plan-control accounting and responsibility accounting was formed. At this time, though preparation of financial statements for the outside still was the major piece of work to the accountants, but was not the final request of enterprise, also not the ultimate goal of the accounting work. Servicing for enterprise management 
and improving the competitiveness of enterprises in the market has become the first target of the accounting, and leads the development direction of the accounting works and accounting organizations.

\section{The Historical Evolution of Accounting Discipline Classification}

\subsection{Guan-Ting Accounting Belongs to Public Finance}

In absolute society, in order to consolidating and maintenance centralized rule, the ruler must implement economic centralization. Centralized economic must depend upon the security of economic organization building, financial and accounting organization construction is the most fundamental ways. The stanchion of the implementation of the national administrative power is in the public finance, and the control of the public financial power relies on the accounting, if there are not details of the accounting information provided by accounting work, the public financial work can't proceed. In order to formulate and implement fiscal policy, the tax authorities, account division, and national treasury three specific organization coordinate each other; the joint work is supportive to national finance. As the most representative in this accounting phase of development, both the working content and organization form of the Guan-Ting accounting serviced for national finance work, and is a branch of public financial work. The accounting work of Guan-Ting accounting period, fully embodied the goal of Guan-Ting accounting at that time is to safeguard centralization of state power. For example, the tang dynasty (7th century AD) implemented a kind of administration system called San-Sheng-Liu-Bu-Zhi, i.e. three ministries and six departments in the central government. The Hu-Bu under the Shang-Shu-Sheng, one of the three ministries, was in charge of financial revenue and expenditure work of the government. The position of the Hu-Bu ranked only second to the $\mathrm{Li}-\mathrm{Bu}$ that was in charge of government officials. The $\mathrm{Hu}-\mathrm{Bu}$ was in charge of registering the fields and population nationwide, levying tax and accounting. The Hu-Bu had four divisions, the $\mathrm{Hu}-\mathrm{Bu}$ division was in charge of registering the fields and population nationwide, drawing up tax names, levying tax, and so on; the Du-Zhi-Bu division was in charge of making budget, and nationwide accounting that include the government office from the central to the local must report the accounting results and balance of properties; the Jin-Bu division was in charge of examining and verifying of the receiving and paying of money and silks in the Treasury, and the Tai-Fu-Si set additional was engaged in giving out the money and silks; the Cang-Bu division was in charge of examining and verifying of the receiving and paying of grain nationwide, and the Si-Nong-Si set additional was engaged in giving out the grain. From the administrative system of Tang dynasty, we can see, the Du-Zhi-Bu division charged of accounting work was belonging to the $\mathrm{Hu}-\mathrm{Bu}$ charged of financial work.

In the feudal regime, the accounting department attached to the financial department engaged in the national economic statistics, it reflected the combining of accounting and statistics, and the accounting work belongs to finance work. The subordination relation reflected the accounting work at that time had public finance attribute, at the same time, in the process of the development of history, it didn't disappear, but gradually formed an important branch of the accountancy, financial master budget accounting, and it still used today, and played an important role in fiscal budget and implementation in each country's of the world.

\subsection{Accounting of Financial Statements Belongs to Economics}

Started from the human planned production work, the accounting work of reporting production cost and results appeared, along with productivity development, simple family unit of small-scale peasant economy production mode, gradually gave the place to socialized production mode on the basis of division of labor in society. The trading on the leverage brought the banking industry prosperity; Partnership led to the development of capital markets. At the same time it also brought a huge problem, namely there were a degree of information asymmetry between the operators and the creditors and investors, because of the separation of ownership and management power. The interested parties outside the enterprise urgent need to understand the real operating condition of business enterprise, but they can not go directly into enterprise to understand, thus the goal of accounting work had changed. The original enterprise accounting only serviced for the enterprise operator, who was also the owner, the accountants reported cost and profit, property and debt of the enterprise, etc to the operator. With the development of social economy, external stakeholder became more and more, their requirement to the accounting work also became more and more complicated, this requirement impelled the accountants to provide a series of documents that can highly summarize the business management and easily understand. These documents were the accounting statements that we all know very well today. In order to expand the scope of operation, if the enterprise relied on their own accumulation, the effects were very limited; only through borrowing the debt or attracting new investors, the enterprise could achieve the fast development. In order to know the safety of the loan, the creditors need to know the details of the debt scale, asset scale, and the payment ability, etc. of the enterprise; in order to realize the maintaining and in- 
creasing of capital, the investors need to understand the operating results, profitability, and dividend policy, etc. of the enterprise. All these required the accounting work can provide detailed, professional accounting statements for the external, so far, mainly including the balance sheet which reflected the assets, liabilities and owner's equity of the enterprise; the income statement which reflected the profitability of the enterprise; and the cash flow statement which reflected the ability of acquiring the cash and cash equivalents that could guarantee payment of the enterprise; etc. Preparing the accounting statement, the accountants would use of a large number theory of economics, such as the theory of product cost structure used the labor value theory of economics, and the relationship between assets and income, the analysis of the accounting statements are massively used the economic theory. This embodies the economics attributes of external statements accounting. This adapted to the goal of the external statements accounting, external statements accounting provided the economic data reflecting the operating and management of the enterprise, made the financial analysis by the economics theory, so that the external information users can make the investment and credits decisions. From the emergence to the development so far, accounting statements constantly improve, and are confirmed through making enterprise accounting standards by the national legislative method. It has become an important branch of the accounting, financial accounting, and is widely available in the social economic practices, and plays a role to ensure the national economy operation healthily and smoothly.

\subsection{Management Accounting belongs to Management}

Since enter the 20th century, the enterprise was faced with unprecedented challenges, the shortage of the resources day by day and the rapid development of the science and technology brought the unprecedented fierce external market competition; The limited market limited the enterprise increase sales to obtain development through the developing new markets, the relative fixed channels of financing also limited the source of the capital. Faced with this trouble, the enterprise wanted to develop, the only way was digging into the internal potential. If the enterprise can not increase the profits by increasing the sales, they must reduce the costs to realize the profits increase. Under this challenge, the enterprise accounting work must adapt to the challenge and make great change, the simple recording mode of cost accounting have not adapted to the requirement of fierce market competition, and the standard cost method and budget control arose at the historic moment, the simple cost accounting began to change into the management accounting that serviced for the enterprise management. Since the 1950s, in order to adapt to the needs of modern enterprise management, the management accounting improved the planning \& control accounting, the forecast \& decision accounting and the responsibility accounting etc. further, basically formed the new management accounting system based on the forecast-and-decision accounting and supplemented by the planning-and-control accounting and the responsibility accounting. After 1980s, management accounting theory combined further with the reality that the computer technology gained vigorous development, in order to adapt to new things such as the just-in-time production system, the total quality control (TQC) etc., the JIT non-cumulative costing and the activity-based costing emerged. At this time, although the management accounting still used a lot of economic method, but the goal of the management accounting mainly was helping the enterprise managers forecast and decide, control and evaluate on the enterprise's management, by using of financial accounting information, and realizing the general strategy of the enterprise development. Its essence has been separated from the economics, and become a part of the management discipline; this was adapted to the goal of the management accounting. This shows, the management accounting, as a representative of the modern accounting, although still had some degree of economics attribute, but its essence has been separated from the economics, and become another important branch of the accounting, to improve management, enhance efficiency and realize the overall strategic for the enterprises. At the same time, the theory and method of management accounting, not only applied to the enterprise, its theories of the cost management, forecast decision and control evaluation etc. also applied to other organizations, and even extended to the whole society.

\section{The Prospects of Subject Classification of Accounting}

Throughout the history, the accounting emerged, developed, and formed a series of comparatively perfect theory and method; it has taken a long and tortuous process. When it was born, the accounting is an accessory part of the production.

In the feudal society, in order to conform to the ruler's needs of maintenance of the centralized economic, the accounting gradually became the Guan-Ting accounting that had tight organization structure and fixed the work mode, because of the restrictions of the service object and work target, Guan-Ting accounting belonged to subordinate part of public financial work, from the point of view of modern subject classification, the period of Guan-Ting accounting shall belong to public finance, and the public finance is a branch of applied economics, so, at this time, the accounting was only a tool to service for national finance. Today, public finance budgetary ac- 
counting followed the same trace of the Guan-Ting accounting, still existed as an important part of the formulation and implementation process of the national fiscal policy.

With the outbreak of the industrial revolution, social production turned into an unprecedented and striding development stage, in order to adapt to this demand, the unknown folk accounting obtained rapid development, as a real science accounting was born, the accounting theory developed, the accounting practice perfected further, and the financial accounting that prepared accounting statements finally formed. Financial accounting mainly used the theory and methods of economics, prepared the accounting statements that reflect the enterprise economic information comprehensively, and serviced for the external information users' needs of investment and lending decisions. From the point of view of modern subject classification, financial accounting does not belong to the public finance category, but belongs to the economics category directly; its status had the further promotion.

Enter the 20th century, the theory and method of modern management accounting obtained full development; to this day, it still is the hot spot of the accounting development. Management accounting is different from the traditional financial accounting, it is not only a branch of economics category, but also makes use of the theory of emerging management. The object that it services for transforms from the external information users into the enterprise internal, it reforms the original cost accounting which emphasizes recording primarily, it engages in management by the currency's vision, or services for the management, it helps enterprise managers to forecast, decisive, control and evaluate. From the point of view of modern subject classification, the management accounting has separated from his economics mother's arms, and become a part of the burgeoning management discipline, and it helps to build the direct relationship between the management and the economics by using the unique monetary eyes of the accounting.

Today, the accounting goal is not simply servicing for production, also is not purely servicing for management; is not only servicing for the country, also is not only servicing for the enterprise. Accounting has become an essential indispensable knowledge towards the country, the enterprise and the family, the production, the business operation and the management. Every cell in the social life, as long as, it takes part in economic life and exchange with other subject, it can not be without help of the accounting. The value measurement concept of accounting faithfully reflects the reality of the social life from a unique perspective, she and we are closely related, and her status also should get a positive. With the development of social economy, the cognition of accounting will continue to deepen, and there will be more accounting theory appeared and added to accounting science system, accounting will certainly become an independent discipline, and become an important branch of the whole society science.

\section{REFERENCES}

[1] D.-G. Chen, "The Attribute of the Accounting; Management or Economics?” Management World (Monthly), Vol. 6, 2009, pp. 182-183.

[2] S.-P. Wu, “The Principle of Accounting," Shenyang: Liaoning People’s Publishing House, 1994.8

[3] D.-Y. Guo, “Accounting History Tutorials, Beijing: China financial and Economic publishing house, Vol. 1, 1998.11.

[4] Y.-J. Chen, "Management Accounting Tutorials,” Shanghai: Lixin Accounting Publishing House, 2004.8.

[5] D.-G. Chen and H. Liao, "The Economics Attribute of Accounting, Communication of Finance and Accounting (comprehension), 2009.12, pp. 59-61.

[6] J. M. Putti, H. Weihrich and H. Koontz, "Essentials of Management: An Asian Perspective,” Translator: H.-P. Ding, X.-J. Sun, Beijing: China Machine Press, 1999.1. 